\title{
FACTORS AFFECTING CONSUMER INTEREST IN ELECTRONIC MONEY USAGE WITH THEORY OF PLANNED BEHAVIOR (TPB)
}

\author{
Anton Nugroho*)1, Mukhamad Najib**, Megawati Simanjuntak*** \\ *Master of Management and Business, Business School \\ Bogor Agricultural University \\ **Department Of Management, Faculty of Economics and Management, \\ Bogor Agricultural University \\ ***Department of Family and Consumer Sciences, Faculty of Human Ecology, \\ Bogor Agricultural University \\ ${ }^{1}$ Corresponding author:nugrohobi@yahoo.com
}

\begin{abstract}
There are many factors that influence consumer intention to use electronic money. Based on the theory of planned behavior, behavior intention is formed by the attitude toward behavior, subjective norms and perceived behavioral control. This research aims to analyze attitude, subjective norms and perceived behavioral control that affect consumer intention in the usage of electronic money.Data collection from respondents through a structured questionnaire by self-report. Some questions in the questionnaire were made on a Likert scale with five variations of the answers in very strongly disagreeable order to strongly agree. The respondents are 290 undergraduate students that have never used server-based electronic money. The result showed that the attitude toward behavior did not a significantly affect the behavior intention. While the subjective norms and perceived behavioral control have a significant effect on the behavior intention in the usage of electronic money.
\end{abstract}

Keyword: electronic money, intention, TPB

\begin{abstract}
Abstrak.Terdapat banyak faktor yang mempengaruhi minat konsumen dalam penggunaan uang elektronik. Berdasarkan theory of planned behavior, minat berperilaku dibentuk dari sikap terhadap perilaku, norma subjektif, dan kontrol perilaku yang dirasakan. Penelitian ini bertujuan untuk menganalisis sikap, norma subjektif dan kontrol perilaku yang diterima yang mempengaruhi minat konsumen dalam penggunaan uang elektronik. Pengumpulan data dari responden dilakukan melalui kuesioner terstruktur diisi sendiri oleh responden. Beberapa pertanyaan dibuat pada skala likert dengan lima variasi jawaban dengan urutan sangat tidak setuju hingga sangat setuju. Responden adalah 290 mahasiswa strata satu yang belum pernah menggunakan uang elektronik berbasis server.Teknik sampling yang digunakan adalah judgement sampling (non-probability sampling). Hasil penelitian menunjukkan bahwa sikap terhadap perilaku tidak berpengaruh signifikan terhadap minat. Sedangkan norma subjektif dan kontrol perilaku yang dirasakan berpengaruh signifikan terhadap minat dalam penggunaan uang elektronik.
\end{abstract}

Kata kunci: minat, uang elektronik, TPB 


\section{Introduction}

Bank of Indonesia on 14 August 2014 has launched the Non-Cash National Movement. Non-Cash National Movement is expected to reduce printing and distribution costs of money that can reach 3.5 (three points five) trillion rupiah per year (Yulianto, 2015). Siwinastiti and Nirmala (2014) concluded that non-cash payment transactions using electronic money (e-money) on a long-term positive and significant impact on the demand for currency in Indonesia. Furthermore, GNNT expected to provide benefits such as more practical in the transaction, increasing the public access on the payment system, transparency of transactions, reducing the cost of rupiah management, improving the circulation of money in the economy and more accurate economic planning with the support of transactions recorded completely. Non-cash transaction ratio compared to cash transactions in Indonesia is still low at one percent, this is quite far when compared with neighboring countries like Malaysia which reached 27 percent (Simorangkir, 2016).

Campus environment can be used as a model for the formation of less cash society. According to Ramadani (2016), there is positive and significant influence between the use of electronic money to the consumption expenditure of students. Another point expressed by Parastiti, Mukhlis and Haryono (2015) that KTM (Student ID Card) is integrated, does not increase the use of BRIZZI's electronic money to students. Students who use BRIZZI's electronic money as a means of payment are still deficient. Research conducted by Alam and Sayuti (2011); Burhanudin (2015); and Prasastyo (2015) concluded that attitude, subjective norms and perceived behavior control influence on intention. The success of less cash society in campus environment is expected to be a sample and can be applied in other society.

GNNT is intended to encourage people to use payment systems and noncash payment instruments in payment transactions, either through internet banking, debit cards, credit cards or electronic money. Bank Indonesia cooperates with universities to succeed this movement, one of them is Bogor Agricultural University (IPB). Students not only potential users but also potential to be one of the agents of change/influencer in making cash payments to non-cash.

This payment instrument is expected to accelerate the payment process, more efficiently and safely with a relatively cheaper cost than other electronic payment instruments such as debit cards or credit cards. Non-cash transaction services can use electronic money either in the form of a bassed chip or a bassed server. But in the implementation of the use of electronic money has not become a primary choice for students in buy something. Students who prefer to pay using cash directly to the merchant still found in canteen, because it is considered faster than having to queue at a centralized cashier.In minimarket, after the experiment for 6 ( six) months, there are no students who pay with e-money. This shows the low intention of students to make e-money as a choice of means of payment. The choice of e-money type is also seen in Non-Cash National Movement transaction data conducted in IPB. The electronics offered consist of four chip-based e-money (Flazz, E-Money, Brizzi, and Tap-Cash) and six server-based e-money (BBM 
Money, Rekening Ponsel, T-Cash, Dompetku, T-Money, XL-Tunai). The data shows that from the total transactions Rp 89.137.516, transactions using serverbased electronic money only reached $\mathrm{Rp} 683.999$ or 0.77 percent of total transactions (Figure 1).

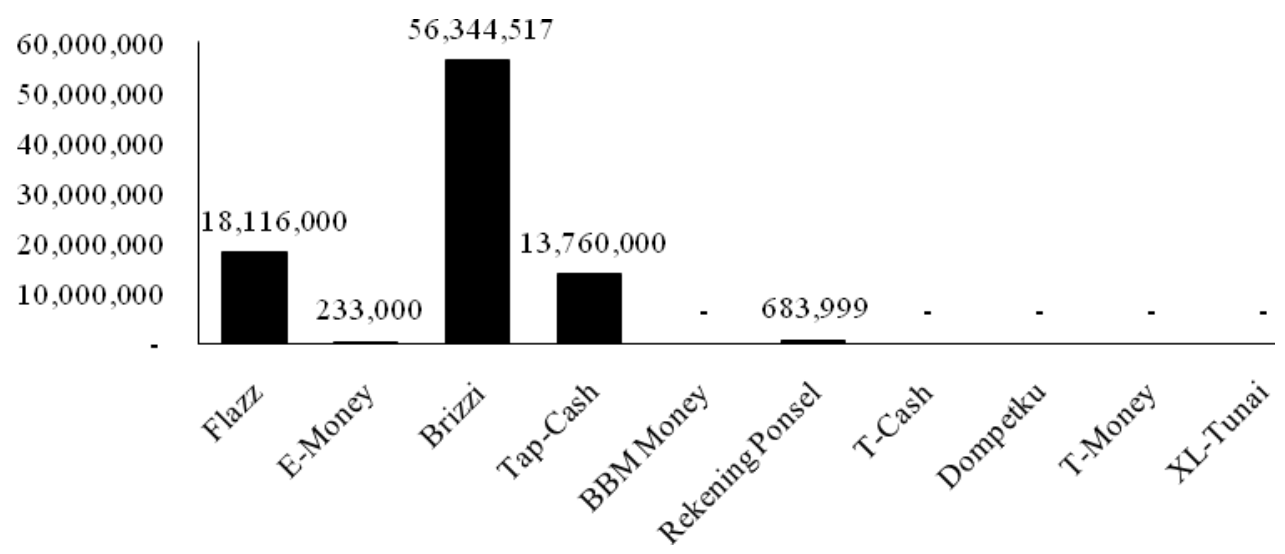

Figure 1 Total of electronic money transactions on GNNT campus IPB Dramaga (September to December 2014)

In order to support the goal of making the student as one of the agents of change in making cash payments to the non-cash, of course, the intention of the students using electronic money becomes important. The purpose of this research is to analyze attitude, subjective norms and perceived behavior control that influence consumer intention in the use of electronic money.

\section{Method}

This research used descriptive research design with survey method. Descriptive research is a research that aims to describe something to describe the fact, population, or specific field in factual and systematic. The survey method is a data collection technique that aims to collect relatively large amount of data in a population. The survey type used in this study is a cross sectional survey, so it is only done at a certain time (Nazir 1998). A survey conducted by providing questions to respondents by using questionnaires as an instrument of data collection from a population. This research was conducted at Dramaga IPB Campus from May to July 2017.

The population of this study is undergraduate students of IPB. Sampling technique conducted in this study is judgment sampling (non-probability sampling). The samples taken are undergraduate students of IPB and never use server-based electronic money. Server-based electronic money is a payment instrument issued by a Bank or institution other than a Bank, based on the value of the money deposited in advance which is stored electronically in the media server and is not a savings as referred to in the law regulating banking (Bank Indonesia). The number of samples taken as many as 290 students.

Data collection from respondents is done through a structured questionnaire. Questionnaires are filled in by the respondents (self-report). Some questions in the questionnaire were made on a scale (scaled response question). 
Scaling technique used Likert scale. Respondents are required to choose one among Likert scales with five variations of the answers in very strongly disagree order to strongly agree. Analysis of the distribution of respondents using top two boxes is to combine the respondents who agree and strongly agree divided by the number of respondents, and the bottom two boxes are to combine the respondents who strongly disagree and disagree divided by the number of all respondents (Anggelina \& Japarianto, 2014). Respondents who are neutral are assumed to be more likely to disagree and are combined into the bottom two boxes.

Variables in this study consist of two types of variables, namely independent variables/exogenous latent variables and dependent variable/endogenous latent variable. The overall variables used and the indicators can be seen in Table 1.

Table 1 Variables used in the study

\begin{tabular}{|c|c|c|c|c|}
\hline Construct & Dimensions & Indicators & Symbol & References \\
\hline \multirow{12}{*}{$\begin{array}{l}\text { Attitude } \\
\text { Toward } \\
\text { Behaviour }\end{array}$} & \multirow{6}{*}{ Behaviour Beliefs } & Practicality & BB1 & \multirow{12}{*}{$\begin{array}{l}\text { Rahmatsyah } \\
\text { (2011) }\end{array}$} \\
\hline & & Security & BB2 & \\
\hline & & Speed & BB3 & \\
\hline & & Lifestyle/trend & BB4 & \\
\hline & & Cheaper & BB5 & \\
\hline & & Easiness & BB6 & \\
\hline & \multirow{6}{*}{$\begin{array}{l}\text { Outcome } \\
\text { Evaluation }\end{array}$} & The importance of Practicality & OE1 & \\
\hline & & The importance of Security & OE2 & \\
\hline & & The importance of Speed & OE3 & \\
\hline & & The importance of & OE4 & \\
\hline & & Lifestyle/trend & OE5 & \\
\hline & & $\begin{array}{l}\text { The importance of Low cost } \\
\text { The importance of Easiness }\end{array}$ & OE6 & \\
\hline \multirow{8}{*}{$\begin{array}{l}\text { Subjective } \\
\text { Norms }\end{array}$} & \multirow{4}{*}{ Normative Beliefs } & Family members & NB1 & \multirow{8}{*}{$\begin{array}{c}\text { Shih dan Fang } \\
\text { (2004), } \\
\text { Rahmatsyah } \\
\text { (2011) }\end{array}$} \\
\hline & & Friends & NB2 & \\
\hline & & Social Community & NB3 & \\
\hline & & Lecturer & NB4 & \\
\hline & \multirow{4}{*}{$\begin{array}{l}\text { Motivation to } \\
\text { Comply }\end{array}$} & Family members & $\mathrm{MC1}$ & \\
\hline & & Friends & $\mathrm{MC} 2$ & \\
\hline & & Social Community & MC3 & \\
\hline & & Lecturer & MC4 & \\
\hline \multirow{7}{*}{$\begin{array}{l}\text { Perceived } \\
\text { Behaviour } \\
\text { Control }\end{array}$} & \multirow{3}{*}{ Control Beliefs } & $\begin{array}{l}\text { Benefits/can be used for } \\
\text { various payment transactions }\end{array}$ & CB1 & \multirow{7}{*}{$\begin{array}{c}\text { Shih dan Fang } \\
\text { (2004), } \\
\text { Rahmatsyah } \\
\text { (2011) }\end{array}$} \\
\hline & & $\begin{array}{l}\text { Knowledge of electronic } \\
\text { money }\end{array}$ & CB2 & \\
\hline & & $\begin{array}{l}\text { The network of electronic } \\
\text { money usage is easy to find }\end{array}$ & CB3 & \\
\hline & \multirow{4}{*}{$\begin{array}{l}\text { Power of Control } \\
\text { Factor }\end{array}$} & Benefits/can be used for & CF1 & \\
\hline & & various payment transactions & & \\
\hline & & $\begin{array}{l}\text { Understand about electronic } \\
\text { money }\end{array}$ & $\mathrm{CF} 2$ & \\
\hline & & $\begin{array}{l}\text { The network of electronic } \\
\text { money usage is easy to find }\end{array}$ & CF3 & \\
\hline \multirow{2}{*}{$\begin{array}{l}\text { Behaviour } \\
\text { Intention }\end{array}$} & & Plan to use & BI1 & \multirow{2}{*}{$\begin{array}{l}\text { Haryono et al. } \\
(2012), \\
\text { Rahmatsyah } \\
(2011)\end{array}$} \\
\hline & & $\begin{array}{l}\text { Intention in using electronic } \\
\text { money in the next six months }\end{array}$ & $\mathrm{BI} 2$ & \\
\hline
\end{tabular}


Theory of Planned Behavior (TPB) stated that intention is influenced by three things, Attitude Toward Behavior (ATB), Subjective Norm (SN) and Perceived Behavior Control (PBC) (Ajzen, 2005). The research framework of this research can be seen in Figure 2. Data process and analysis in this study using the program SPSS 22 and Structural Equation Modeling (SEM) with LISREL 8.30 program. The model measurement test is based on the loading factor value. Loading factor value $>0.5$ can be interpreted that the indicators have met the criteria of the validity test of a convergent latent construct (Ghozali, 2006). The construct analysis consists of the validity and reliability test of the construct. Model validity is represented by Variance Extracted (VE) values. The value of VE> 0.5 indicates that the model has satisfied the terms of good convergent validity. While the reliability model is shown by the value of Composite Reliability (CR). CR value> 0.7 indicates that all latent constructs have good, accurate and consistent reliability. The feasibility test of SEM model is done by testing the goodness of fit. The value of RMSEA $\leq 0.08$ can be interpreted that the model has a good fit. The use of other goodness of fit criteria is GFI, AGFI, IFI, NFI, and CFI, if the resulting value> 0.90 means that the resulting model has the goodness of fit and hypothesis testing theory can be done. Hypothesis testing is based on t-count value, if $t$-count $>t$-table (1.96) means significant influence.

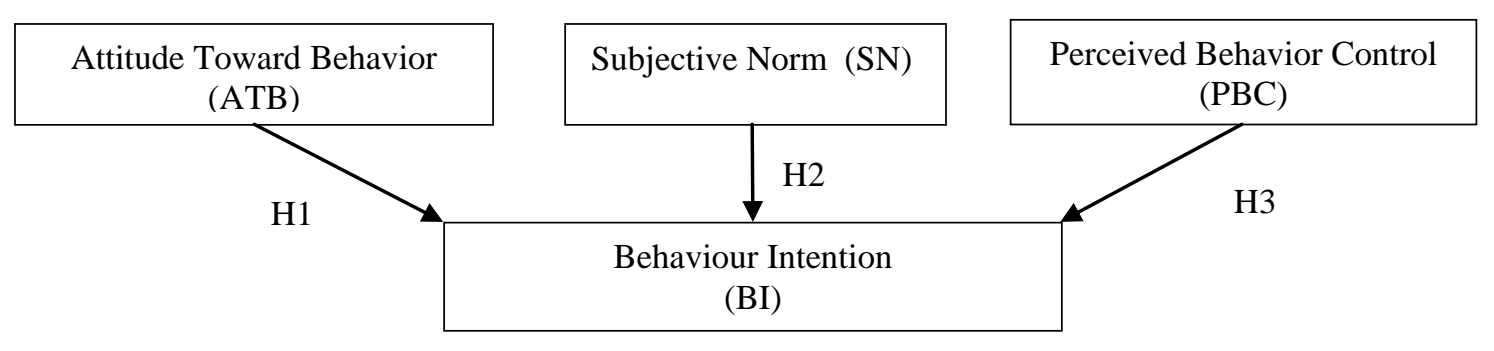

Figure 2 Research Thinking Framework

The research hypothesis is as follows:

H1: Attitudes toward behavior have a significant influence on intention

H3: Control of perceived behavior has a significant influence on intention

$\mathrm{H} 2$ : The subjective norm has a significant influence on intention

\section{Result}

Behavior Beliefs (BB) users of server-based electronic money can be seen in Table 2. Respondents who agree that payment transactions using server-based electronic money is more practical as much as 68.9 percent, while those who disagree only 31.1 percent. A total of 56.9 percent of respondents agree that payment transactions using server-based electronic money more secure, while those who disagree 43.1 percent. Respondents agree that the payment transactions use server-based electronic money faster at 78.3 percent, while those who disagree 21.7 percent. Respondents who agreed that payment transactions using server-based electronic money could follow the trend/lifestyle of 57.6 percent, while those who disagree 42.4 percent. As many as 36.2 percents of respondents agreed that payment transactions using server-based electronic money is cheaper, 
while 63.8 percent disagree. And respondents who agree that payment transactions using server-based electronic money easier as much as 64.8 percent, while those who disagree 35.2 percent.

In the Outcome Evaluation (OE) dimension of the use of server-based electronic money, the respondents agree that the practicality of payment transactions using server-based electronic money was important as much as 75.2 percent, while those who disagree 4.8 percent. Respondents agree that security and speed were important in payment transactions using server-based electronic money of 90.7 percent and 79.6 percent, while those who did not believe were 9.3 percent and 20.4 percent. As many as 26.2 percents of people agree on the importance of following trends or lifestyles, while those who disagree as much as 73.8 percent. Respondents who agree that the cheaper cost and ease of payment transactions using server-based electronic money were important 81.0 percent and 87.9 percent, while 19.0 percent and 12.1 percent disagreed.

Table 2 Distribution of indicators of attitudes toward behavior of server-based electronic money users

\begin{tabular}{llcc}
\hline \multicolumn{1}{c}{ Dimensions } & \multicolumn{1}{c}{ Indicators } & Disagree & Agree \\
\hline Behavior & More practical & 31.1 & 68.9 \\
Beliefs(BB) & Safer & 43.1 & 56.9 \\
& Faster & 21.7 & 78.3 \\
& Following the trend/lifestyle & 42.4 & 57.6 \\
& Cheaper & 63.8 & 36.2 \\
& Easier & 35.2 & 64.8 \\
\hline Outcome & The importance of practicality & 24.8 & 75.2 \\
Evaluation (OE) & The importance of security & 9.3 & 90.7 \\
& The importance of speed & 20.4 & 79.6 \\
& The importance of following & 73.8 & 26.2 \\
& trend/lifestyle & 19.0 & 81.0 \\
& The importance of cheaper & 12.1 & 87.9 \\
\hline
\end{tabular}

Respondents' attitudes toward subjective norms can be seen in Table 3. In the normative belief dimension of respondents who agree to the recommendation of family, friends, social community and lecturers to use server-based electronic money 16.6 percent, 25.9 percent, 26, 5 percent and 13.1 percent respectively, while those who did not agree were 83.4 percent, 74.1 percent, 73.5 percent and 86.9 percent, respectively. In the motivation dimension of respondents who agree to raise the recommendation of family, friends, social community and lecturers to use server-based electronic money each of 34.8 percent, 22.1 percent, 24.5 percent and 19.0 percent, while those who disagree each with 65.2 percent, 77.9 percent, 75.5 percent and 81.0 percent respectively. 
Table 3 Distribution of indicators to the subjective norms of server-based electronic money users

\begin{tabular}{llcc}
\hline \multicolumn{1}{c}{ Dimensions } & \multicolumn{1}{c}{ Indicators } & Disagree & Agree \\
\hline Normative Belief & Recommendation from family members & 83.4 & 16.6 \\
(NB) & Recommendation from friends & 74.1 & 25.9 \\
& Recommendation from social & 73.5 & 26.5 \\
& community & 86.9 & 13.1 \\
\hline Motivation to & Recommendation from lecturer & 65.2 & 34.8 \\
Comply (MC) & Following family recommendation & 77.9 & 22.1 \\
& Following friends recommendation & 75.5 & 24.5 \\
& recommendation community & 81.0 & 19.0 \\
\hline
\end{tabular}

Respondent's attitudes toward perceived behavior control can be seen in Table 4. In the dimension of control belief, respondents who agree that serverbased electronic money is useful / can be used on various payment transactions as much as 49.6 percent, while those who disagree as much as 50.4 percent. A total of 26.5 percent of respondents agree that know about server-based electronic money, while those who disagree as much as 73.5 percent. And as many as 32.8 percents of respondents agree that place of use server-based electronic money is easy to find, while those who disagree as much as 67.2 percent.

Table 4 Distribution of indicators to perceptions of control of user-based electronic money usage

\begin{tabular}{llcc}
\hline \multicolumn{1}{c}{ Dimensions } & \multicolumn{1}{c}{ Indicators } & Disagree & Agree \\
\hline $\begin{array}{l}\text { Control Belief } \\
\text { (CB) }\end{array}$ & $\begin{array}{l}\text { Very useful / can be used for various payment } \\
\text { transactions }\end{array}$ & 50.4 & 49.6 \\
& $\begin{array}{l}\text { Know much about server-based electronic } \\
\text { money }\end{array}$ & 73.5 & 26.5 \\
& The network or place of use is easy to find & 67.2 & 32.8 \\
\hline $\begin{array}{l}\text { Control Factor } \\
\text { (CF) }\end{array}$ & $\begin{array}{l}\text { If it has many benefits / can be used for various } \\
\text { payment transactions }\end{array}$ & 18.0 & 82.0 \\
& $\begin{array}{l}\text { If understand about its use } \\
\text { If the availability of network usage a lot / easy to } \\
\text { find }\end{array}$ & 22.7 & 77.3 \\
& 20.3 & 79.7 \\
\hline
\end{tabular}

In the control factor dimension, respondents who agree that will use server-based electronic money if it has many benefits / can be used for various payment transactions, understand about its usage and availability of network that many / easy to found as much as 82.0 percent, 77.3 percent, and 79.7 percent, while those who did not agree respectively as much as 18.0 percent, 22.7 percent, and 20.3 percent.

Distribution indicator of intention using server-based electronic money can be seen in Table 5. Respondents who agree on a plan to use server-based electronic money as much as 50.3 percent, while who disagree as much as 49.7 percent. As many as 37.2 percents of respondents agree to use within 6 (six) months ahead, while those who disagree as much as 62.8 percent. As many as 35.6 percents of respondents agree to recommend to others, while those who disagree as much as 64.4 percent. 
Table 5 Distribution of indicator of user intention in server-based electronic money

\begin{tabular}{llcc}
\hline \multicolumn{1}{c}{ Dimension } & \multicolumn{1}{c}{ Indicator } & Disagree & Agree \\
\hline $\begin{array}{l}\text { Behavioral } \\
\text { Intention (BI) }\end{array}$ & Plan to use & 49.7 & 50.3 \\
& Will use in the next six months & 62.8 & 37.2 \\
\end{tabular}

Exogenous latent Attitude Toward Behavior (ATB) users are explained by two dimensions of Behavioral Beliefs (BB) and Outcome Evaluation (OE) of 0.91 and 0.81 . The dimensions of behavior belief (BB) are explained by six indicators, ie more practical transactions (BB1), safer transactions (BB2), faster transactions (BB3), following trends / lifestyles (BB4), cheaper cost (BB5) and easier transactions (BB6). The highest load factor value is found on safer transaction indicator (BB2) which is 0.78 , while the smallest is indicated by trend/lifestyle (BB4) that is equal to 0.63 . This shows that security in transactions more effectively increases the confidence of user behavior so that attitudes toward user behavior will be better. While following the trend or lifestyle is less a consideration for consumers in behaving than other indicators (Figure 3).

The dimension of the results of the outcome evaluation $(\mathrm{OE})$ are described by 6 indicators of importance of practicality (OE1), importance of safety (OE2), importance of speed (OE3), importance of following trends / lifestyles (OE4), importance of cheaper cost (OE5) and the importance of easiness (OE6). The highest loading factor value is in the indicator of the importance of speed in transactions (OE3) that is 0.82 , while the smallest is in the indicator of the importance of following the trend/lifestyle (OE4) that is equal to 0.58. This shows that the speed in transactions more effectively improve attitudes toward the evaluation results received so that attitudes toward user behavior will better.

An exogenous latent variable of Subjective Norms (SB) of the user is explained by two dimensions of Normative Beliefs (NB) and Motivation to Comply (MC) of 0.80 and 0.86 respectively. The dimension of normative belief (NB) is explained by four indicators that are recommendation from the family member (NB1), recommendation from a friend (NB2), recommendation from social community (NB3) and lecturer (NB4). The highest loading factor value is indicator of recommendation from a friend as much as 0.86 , while the smallest is the recommendation from the lecturer (NB4) as much as 0.70 . This suggests that the recommendation from a friend more effective increases normative beliefs also to improve subjective norm. While recommendation from lecturer is less considered by consumers in determining attitude (Figure 3 ).

The dimension of motivation to comply (MC) is explained by four indicators that following recommendation of family (MC1), recommendation of friend (MC2), recommendation of social community (MC3) and recommendation of lecturer (MC4). The highest loading factor value is the indicator of following recommendation of friends (MC2) and following the social community recommendation with the same value of 0.94 , while the smallest is the indicator of following recommendation of the family (MC1) of 0.82. This suggests that the recommendation of friends and social communities more effective increases the 
motivation to adhere to using server-based electronic money in payment transactions there by improving subjective norms.

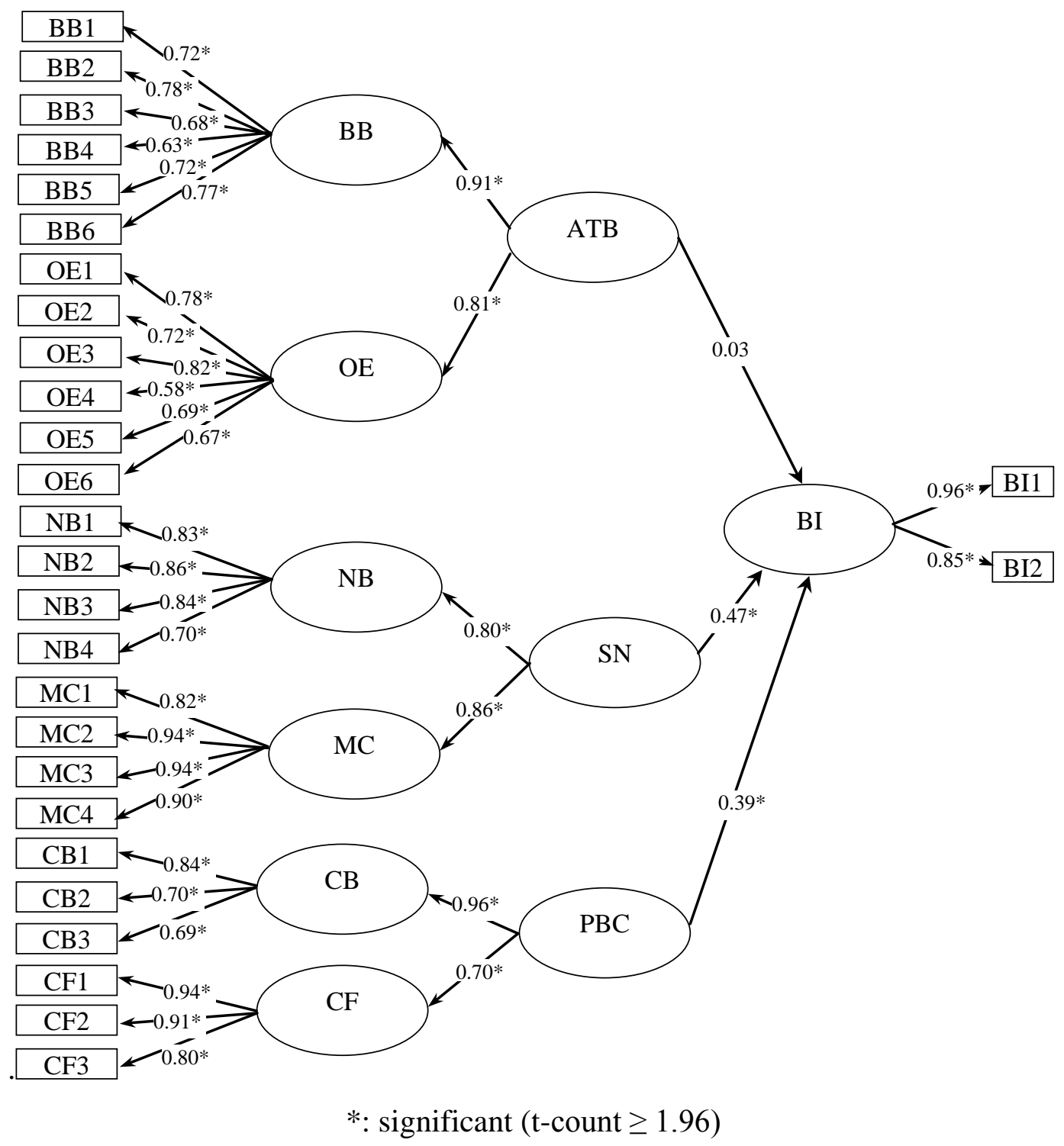

Figure 3 Loading factor model SEM

Exogenous latent variable Perceived Behavioral Control / $\mathrm{PBC}$ is described by two dimensions, Control Belief $(\mathrm{CB})$ and Control Factor $(\mathrm{CF})$ respectively by 0.96 and 0.70 . The dimension of control belief $(\mathrm{CB})$ is explained by three indicators that are very useful/can be used on various payment transactions (CB1), know much about server-based electronic money (CB2) and the network or place of use is easy to find (CB3). The highest loading factor value is on the indicator of very useful / can be used in various payment transactions (CB1) as much as 0.84 , while the smallest are found in the indicator of the network or place of use is easy to find (CB3) that is equal to 0.69. This suggests that many of the benefits/usability of using server-based electronic money on more effective 
payment transactions increases the confidence of controls so that perceived behavior control increases (Figure 3).

The dimensions of control factor (CF) is explained by three indicators that will use server-based electronic money if it has many benefits / can be used for various payment transactions (CF1), will use server-based electronic money if it understands its use (CF2) using server-based e-money if the availability of network usage is large/easy to find (CF3). The highest loading factor value is the indicator of will use server-based electronic money if it has many benefits /can be used for various payment transactions (CF1) as much as 0.94 , while the smallest is in the indicator of will use server-based money if the availability of network usage much/easy to find (CF3) that is equal to 0.80 . This suggests that the increased benefits/usability of server-based electronic money on more effective payments increases the control factor so that perceived behavior control increases.

Endogenous latent variables of Behavior Intention (BI) are explained by two indicators namely plan to use (BI1) and intention in using electronic money in the next six months (BI2). The highest loading factor value can be in the indicator of plan to use (BI1) that is equal to 0.96 , while the intention in using electronic money in the next 6 (six) months (BI2) is 0.85.This indicates that consumer intention is more likely to plan for using server-based electronic money as a means of payment (Figure 3).

\section{Discussion}

The influence of attitudes toward behavior (ATB) on the intention of using server-based electronic money is shown with the value of loading factor of 0.03 and the value of t-count 0.43 . The loading factor value shows that the influence of attitudes toward the intention of using server-based electronic money is 0.03 . the t-count value $(0.43)$ is smaller than the t-table value (1.96) at the 95 percent confidence level. This shows that Attitude Toward Behavior (ATB) has no significant influence on Behavior Intention (BI). In accordance with Annilda (2017); Farida and Mahmud (2014); Handika and Sudaryanti (2017) that Attitude Toward Behavior has no significant influence on Behavior Intention.

The influence of Subjective Norm (SN) on the intention of using serverbased electronic money is shown with loading factor value of 0.47 and t-count value 4.45 . The value of loading factor shows that the influence of subjective norm to the behavior intention of using server-based electronic money is 0.47 . The t-count value (4.45) is greater than the t-table value (1.96) at the 95 percent confidence level. This indicates that Subjective Norms (SN) has an influence on the Behavior Intention (BI). In accordance with the research result of Alam and Sayuti (2011); Hatta, Baihaqi and Rahmahdaniati (2017); Fatmasari and Wulandari (2016); Knabe (2012); Riyanti (2015); Curz, Suprapti and Yasa (2015); Burhanudin (2015); Handika and Sudaryanti (2017); Wijayanti and Putri (2016); Farida and Mahmud (2014); Prasastyo (2015); Tjahjono, Maryati and Fauziyah (2013), Urban, Zverinova and Scasny (2012); Rustam, Widya and Rukhviyanti (2015) and Rahmatsyah (2011) that subjective norms have a significant influence on intention / behavior intention. 
The influence of perceived behavior control (PBC) on behavior intention (BI) the use of server-based e-money is shown by loading factor value 0.39 and $\mathrm{t}-$ count 2.67. The value of the loading factor shows that the influence of perceived behavior control on the behavior intention of using server-based electronic money is 0.39 . The t-count value (2.67) is greater than the t-table value (1.96) at 95 percent confidence level. This indicates that Perceived Behavioral Control (PCB) has a significant influence on Behavior Intention (BI). In accordance with the results of research Curz, Suprapti and Yasa (2015); Burhanudin (2015); Handika and Sudaryanti (2017); Rahmatsyah (2011); Annilda (2017); Knabe (2012) and Prasastyo (2015) that perceived behavioral control has a significant influence on behavior intention.

\section{Conclusion and Recommendation}

\section{Conclusion}

From the results of this study can be concluded that consumer intention in using server-based electronic money is influenced by subjective norms that greatest described by following recommendation of friends and social communities and perceived behavioral control that greatest described by the benefit /usability of using server-based electronic money on various payment transactions. Of the two factors, the greatest influence is subjective norms.

\section{Recommendation}

The usage of server-based electronic money as a means of payment certainly involves buyers and sellers. This study only studied the factors that influence consumer intention in the use of server-based electronic money as a means of payment (as a buyer). The next research can examine the factors that influence intention seller or service provider in receiving payment using electronic money.

\section{References}

Ajzen, I. (2005) . Attitudes personality and behavior ( $2^{\text {nd }}$ edition).Berkshire. UK. Open University Press-McGraw Hill Education.

Alam S. S., \& Sayuti N. M. (2011). Applying the theory of planned behavior (TPB) in halal food purchasing [Abstract]. International Journal of Commerce and Management, 21 (1), 8-20.

Anggelina J., \& Japarianto E. (2014). Analisis pengaruh sikap, subjective norm dan perceived behavioral control terhadap purchase intention pelanggan 
SOGO Department Store di Tunjungan Plaza Surabaya. Jurnal Strategi Pemasaran, 2(1), 1-7.

Annilda, F. (2017). Faktor yang mempengaruhi minat pengguna internet banking pada usia produktif di Bank XYZ Bogor(Master's thesis). Sekolah Pascasarjana Institut Pertanian Bogor, Bogor.

Bank Indonesia. (2009). Meta data. Retrieved from http://www.bi.go.id/id/ statistik/metadata/sistempembayaran/Documents/MetadataEMoney.pdf

Burhanudin. (2015). Aplikasi theory of planned behavior pada intensi mahasiswa untuk berwirausaha.Jurnal Bisnis dan Ekonomi, 6 (1), 60-72.

Cruz, L., Suprapti N. W. S., \& Yasa N. Y. K. (2015). Aplikasi theory of planned behavior dalam membangkitkan niat berwirausaha bagi mahasiswa fakultas ekonomi UNPAZ, Dili, Timor Leste.E-Jurnal Ekonomi dan Bisnis Universitas Udayana, 4 (12), 895-920.ISSN : 2337-3067.

Farida, I., \& Mahmud. (2014). Pengaruh theory of planned behavior yang berdampak pada intensi berwirausaha mahasiswa. Economics \& Business Research Festival.ISBN : 978-979-3775-555-5

Fatmasari, D., \& Wulandari, S. (2016). Analisis faktor-faktor yang mempengaruhi minat mahasiswa dalam penggunaan APMK.Jurnal Penelitian Hukum Ekonomi Syariah, 4 (1). ISSN P: 2355-0805 ISSN E:2549-4112.

Handika, M. F. D., \& Sudaryanti, D. (2017). Analisis faktor-faktor yang mempengaruhi niat mahasiswa melakukan tindakan wishtleblowing (studi pada mahasiswa akuntansi STIE Asia Malang). Jurnal Ilmiah Bisnis dan Ekonomi Asia), 11 (1), 56-63.

Haryono, T., Sumarwan, U., Saefuddin, A. \& Hartoyo. (2012). Structural model of factors influencing consumer' intention to use natural gas: an application of planned behavior theory. Global Advanced Research Journal of Educational Research and Review, 1 (10), 244-252. ISSN: 2315-5132

Hatta, M., Baihaqi, \& Rahmahdaniati, R. (2017). Perilaku berbagi pengetahuan akuntansi pada dosen akuntansi Kota Bengkulu: pendekatan theory of planned behavior (TPB). Jurnal Akuntansi, Ekonomi Dan Manajemen Bisnis,5 (1), 26-44. ISSN: 2548-9836.

Knabe, A.P. (2009). Applying Ajzen's theory of planned behavior to study of online course adoption in public relations education. (Dissertations). Marquette University.

Nazir, M. (1998). Metode Penelitian. Jakarta (ID): Ghalia Indonesia.

Parastiti, D. E., Mukhlis, I., \& Haryono, A. (2015). Analisis penggunaan uang elektronik pada mahasiswa fakultas ekonomi universitas negeri malang (studi kasus: uang elektronik brizzi). Jurnal Ekonomi dan Studi Pembangunan Universitas Negeri Malang, 7 (1).ISN 2502-7115.

Prasastyo, K. W. (2015). Aplikasi theory of planned behavior dalam intensi pembelian apartemen di wilayah Jakarta dengan domisili sebagai variabel moderating. Jurnal Bisnis dan Akuntansi, 17 (02), 134-142. ISSN 14109875

Rahmatsyah, D. (2011). Analisa faktor-faktor yang mempengaruhi minat penggunaan produk baru (Studi kasus : uang elektronik kartu flazz BCA) (Master'sthesis). Fakultas EkonomiUniversitas Indonesia, Depok. 
Ramadani, L. (2016). Pengaruh penggunaan Kartu Kredit dan Uang Elektronik (emoney) terhadap pengeluaran konsumsi mahasiswa. Jurnal Ekonomi dan Studi Pembangunan, 8 (1). ISSN (P) 2086-1575 E-ISSN 2502-7115.

Riyanti.(2015). Itensi mencontek ditinjau dari theory of planned behavior. Jurnal Ilmiah Psikologi Terapan, 3 (2).ISSN : 2301-8267

Rustam, A., Widya, Y., \&Rukhviyanti, N. (2015). Pengaruh minat individu terhadap penggunaan mobile banking (m-banking): model kombinasi technology acceptance model(tam) dan theory of planned behavior (TPB). Jurnal Informatika dan Sistem Informasi, 7 (1). ISSN 2085-8795

Simorangkir, E. (2016, November 1). Soal Penggunaan Uang Elektronik. RI Masih Kalah dari Malaysia. Detik Finance. Retrieved from https://finance.detik.com/moneter/3334330/soal-penggunaan-uangelektronik-ri-masih-kalah-dari-malaysia.

Siwinastiti, L., \& Nirmala, T. (2014). Analisis pengaruh penggunaan alat pembayaran menggunakan kartu (APMK) dan uang elektronik (E-Money) terhadap permintaan uang kartal di Indonesia. Jurnal Ekonomi Pembangunan, 3 (2), 195-210. ISSN : 2302-9595.

Shih, Y. Y., \& Fang, K. (2004). The use of a decomposed theory of planned behavior to study internet banking in Taiwan. Internet Research, 14(3), 213223.

Tjahjono, H. K., Maryati, T., \& Fauziyah (2013). Intensi mahasiswa Yogyakarta berwirausaha berbasis teknologi informasi (TI). Jurnal Siasat Bisnis, 17 (1), 17-27. ISSN : 0353 -7565.

Urban, J., Zverinova, I., \& Scasny, M. (2012). What motivates Czech consumers to buy organic food. Sociologicky Casopis, 48(3),709-736.

Wijayanti, A. W., \& Putri, G. A. (2016). Model theory of planned behavior (TPB) untuk memprediksi niat mahasiswa melakukan kecurangan akademik. Jurnal Manajemen dan Kewirausahaan, 14 (2), 189-197.

Yulianto, E. (2015, February 4). Biaya cetaknya Rp 3.5 triliun setahun. BI: Uang Tolong Dirawat. Detik Finance. Retrieved from http://finance.detik.com/ moneter/2823602/biaya-cetaknya-rp-35-triliun-setahun-bi-uang-tolongdirawat. 